\title{
THE POTENTIAL IMPACT OF THE CISG ON THE COMMON LAWS OF ENGLAND AND THE REPUBLIC OF IRELAND: \\ A LEGAL ANACTATAXIS OR A TRIVIAL MATTER OF IMPLEMENTATION? THE LESSONS OF COMPARATIVE LAW
}

\author{
Antonios Platsas
}

\section{INTRODUCTION}

This article is based on the speculative hypothesis that the United Kingdom ("UK") as well as the Republic of Ireland ("Ireland") will eventually implement the United Nations Convention on Contracts for the International Sale of Goods 1980 (“CISG 1980") into their legal systems.

Out of the 25 member states of the European Union ${ }^{1}$ only 5 have yet to accede to the CISG 1980: Cyprus, the Republic of Ireland, Malta, Portugal and the United Kingdom; all of them are by and large common law systems with the exception of Portugal. However, the article will focus on the British and Irish "non-compliance" with the CISG 1980 and the potential modifications that their trade law systems would have to face to come up to terms with a potential implementation of the CISG 1980.

The analysis is by way of a comparison between the current common trade laws of England and Ireland with the CISG 1980 (and to a certain extent with the CISG compliant nations). ${ }^{2}$ This is followed by an analysis as to why the implementation of the CISG 1980 will amount to a legal anacatataxis ${ }^{3}$ rather than a mere triviality of implementation in these countries.

\footnotetext{
* LLB Coventry University \& University of Potsdam, LLM International Business Law, London School of Economics, University of London, Researcher in Comparative Law and Legal Methodology Trinity College, University of Dublin.

${ }^{1}$ On the basis that all 10 candidate states will join the European Union by May 2004.

2 There are now 62 contracting states to the CISG from all regions of the world. These also include significant non-European trade partners of the UK and the Ireland such as the USA, Canada and Australia.

${ }^{3}$ Whole reshuffling or restructuring.
} 


\section{A PLETHORA OF DIFFERENCES BETWEEN COMMON TRADE LAW AND THE CISG 1980: A PLETHORA OF COMPARISONS}

Make no mistake, the CISG 1980 and the common law rules of the respective trade laws of England and Ireland are worlds apart. The legal comparatist identifies approximately ten grounds of comparison ${ }^{4}$ between the CISG 1980 and Anglo-Irish commercial law ("common law"). On the face of it, the differences appear insurmountable. However, it will be suggested herein that even if this is so, the Anglo-Irish legal system could embrace the notions and mechanics of the Convention.

\section{(a) The concept of "good faith" under CISG 1980}

The first major difference relates to the concept of "good faith" recognised under Article 7 (1) CISG 1980. It is questionable as to what extent the notion of good faith applies in international sale of goods under the Convention. A significant point to note is that the US legal system has generally accepted this notion in the formation of international contracts for the sales of goods bringing the CISG into force since $1988 .{ }^{5}$

On the other hand and on a macro-comparative basis, one notes the rather explicit absence of "good faith" between traders in Anglo-Irish law, with the exception of consumer contracts due to the influence of European Union Law ("EU Law"). ${ }^{6}$ The case remains, however, that English Law does not generally recognise good faith in commercial contracts at the stage of performance and enforceability of the contracts. In Re Moore \& Co v Landauer \& Co the plaintiff agreed to sell to the defendant canned fruit in cases of thirty. ${ }^{7}$ However, upon delivery the fruit was packed in cases of twenty-four. It was held that the buyer was entitled to reject the goods since the description of the goods had not been complied with. This case illustrates that "good faith" may not intervene to the

\footnotetext{
${ }^{4}$ Although comparative law is mainly engaged with comparisons of differences, it could be used to highlight similarities too. Thus, a ground of comparison may well be either a difference or a similarity; though as it is apparent, it is differences mainly that one meets in a comparison of the CISG 1980 and Anglo-Irish trade law.

${ }^{5}$ The United States of America signed the CISG on the 31of August 1981, ratified it on the 11of December 1986 and brought into effect on the 1 of January 1988.

${ }^{6}$ Prior to Council Directive 93/13/EEC there was an almost complete absence of good faith in consumer contracts of sale in the UK and the Ireland. A good analysis on the impact of this directive remains the text of Professor Hugh Collins. See Hugh Collins, "Good Faith in European Contract Law”, Oxford Journal of Legal Studies (1994). The latter text remains the most authoritative text on the effect of good faith in European Law in general and the British law of consumer contracts in particular.
}

7 [1921] 2 KB 519. 


\section{THE DENNING LAW JOURNAL}

rescue of the plaintiff seller, if he has failed to comply either with the description or the packaging of the goods in question. This case remains a good example of the very limited application of the concept of "good faith" in common law. In Arcos $v$ Ronaasen ${ }^{8}$ the buyers were entitled to repudiate the contract for mere breach of condition, but really in order to take advantage of the falling market price of timber. This was allowed by way of the court's construction. The position in Irish law is analogous. The position of the American trade law ${ }^{9}$ is closer to the CISG 1980 model.

\section{(b) Conformity of goods}

The second major difference between the trade laws of England and Ireland and the CISG 1980 relates to the conformity of the goods of the contract in question. In particular, misrepresentation under Article 25 CISG 1980 occurs only if the breach has been "fundamental". A fundamental breach occurs when the party in breach has caused detriment to the innocent party and the party in breach did not foresee this. ${ }^{10}$ It is generally accepted that common law courts are far more generous than the CISG 1980 on misrepresentation, whilst rescission is not allowed, if the goods have been accepted as in Leaf $v$ International Galleries. ${ }^{11}$ Additionally, when it comes to conformity of goods, the meaning of the word "particular" presents difficulties between the common law and the CISG 1980; thus, under Article 35 (2) (b) CISG 1980 fit for any "particular purpose" has been taken to mean a "special purpose", whilst under Preist $v$ Last $^{12}$

\footnotetext{
${ }^{8}$ [1933] AC 470.

${ }^{9}$ For this a mere reference to article 2-103 (1) (b) of the Uniform Commercial Code 1952 (as amended) should suffice. Article 2-103 (1) (b) (May 1, 1998, Draft) defines good faith as follows: "Good faith" in the case of a merchant means honesty in fact and the observance of reasonable commercial standards of fair dealing in the trade.

${ }^{10}$ In order for the buyer to claim this, he must make a declaration of avoidance by notice to the party in breach as in article 26 CISG 1980. If this succeeds then "avoidance" under article 49 CISG 1980 is the case. The seller too, if he is the innocent party can claim avoidance under article 64 CISG 1980. Obviously the provisions on damages (articles 74-77 CISG) may also be triggered.

${ }^{11}$ [1950] 2 KB 86. The main issue was that of a mistake discovered after many years by the plaintiff in relation to a sale of painting; it was said inter alia that an action could not have been based on mistake, since there was no error in what was handed over. The picture sold was a specific one. The parties were agreed in the same terms on the same subject matter and that has been sufficient to make a contract. Acceptance of the specific good in question had already occurred.

${ }^{12}$ [1903] 2 KB 148.
} 


\section{THE DENNING LAW JOURNAL}

"particular purpose" has to be taken to mean a "commonplace purpose". ${ }^{13}$ Furthermore, a point to be made is that Article 35 CISG does not make allowance for automatic rejection of the goods. Common law takes a significantly different approach on this and therefore in Arcos $v$ Ronaasen ${ }^{14}$ it was held inter alia that the description of the goods amounts to a condition. A breach of condition such as misrepresentation for instance is accordingly a genuine basis for rejection rights to arise in common law. Further, whilst under article 38 CISG 1980 there is an obligatory duty to examine the goods upon delivery, it would seem that no such duty exists under common law (unless it is expressly prescribed in the terms of the contract). Consequently, if common law per se does not recognise any such duty, the inspection of the goods by the purchaser must be seen at best as a right of the latter only rather than a duty as in the CISG 1980.

\section{(c) Anticipatory breach}

Thirdly, the attitudes of the CISG 1980 and common law towards the notion of anticipatory breach vary. Thus, under article 71 (1) CISG 1980 "a party may suspend the performance of his obligations if, after to the conclusion of the contract, it becomes apparent that the other party will not perform a substantial part of his obligations..."15 As the notice requirement is very usual in the CISG 1980, the party intending to suspend performance after the conclusion of the contract must give reasonable notice to the other party. ${ }^{16}$ Accordingly, even though the notion of anticipatory breach is recognised to a certain extent in common law, it does not successfully tackle cases in a systematic and organised manner of the CISG. ${ }^{17}$ This is surely due to the fact that suspension or anticipatory breach is seen not as a matter of course but rather as a matter of

${ }^{13}$ See Michael Bridge The International Sale of Goods: Law and Practice, (Oxford OUP 1999) at p 80 (para. 3.14). Additionally, the statutory expression of Preist $v$ Last can be found in s 14 (1) of the British Sale of Goods Act 1979 (as amended) [hereinafter SOGSA 1979] and s 10 of the Irish Sale of Goods and Supply of Services Act 1980 (old s.14 (1) SOGSA 1893) [hereinafter SOGSASOSA 1980].

${ }^{14}$ [1933] AC 470.

${ }^{15}$ That is if the party in that cannot perform (a) is seriously deficient in his ability to perform or non-creditworthy; or (b) his conduct in preparing to perform or in performing the contract is makes it apparent that he will not perform a substantial part of his obligations as in Article 71 (1) (a) and (b).

${ }^{16}$ As in article 72 (2) CISG.

17 See Universal Cargo Carriers Corporation v Citati [1957] 2 QB 401. The case provides us with the criteria for anticipatory breach to arise in English law; these were stated by Devlin J. 


\section{THE DENNING LAW JOURNAL}

exception in common law. ${ }^{18}$ Bearing this in mind, it would seem that the traditional perception of common law does not give formal recognition to anticipatory breach per se and that is why the approach of the CISG 1980 towards anticipatory breach is seen as a major point of departure from common law, ${ }^{19}$ even if statute law may have made some indirect allowance for this in common law systems. ${ }^{20}$

\section{(d) Termination}

Fourthly, the CISG 1980 treats avoidance or termination of the contracts very differently from common law. ${ }^{21}$ As already noted the CISG 1980 requires a "fundamental breach" for the termination of the contract to take effect. Nevertheless, it is particularly onerous for the innocent party to prove this or rather to override the requirements for this. ${ }^{22}$ One has to override the relevant legal requirements of Article 25 CISG 1980 and then serve notice of this to the party in fundamental breach under Article 26. This is the only way that an innocent party can successfully disengage himself from his obligations under the CISG 1980 for termination of contract to arise. This attitude, however, would characterise the CISG 1980 as a "pro-contractual" legal instrument, for the CISG 1980 takes such a stance that the contracts are to be upheld, unless things "go terribly wrong" as in the case of fundamental breach. Common law, on the other, takes a significantly stricter stance on this; it seems to be "less pro-contractual". For instance, in the case of a common law contract the test is whether the term breached is a condition, even if the breach is only minor. ${ }^{23}$ And this for good reason, namely, legal certainty. Even if common law contracts such as the ones

\footnotetext{
${ }^{18}$ Suspension in common law arises only in the rather rare instances where the buyer's duty to make payment is not essential, whilst the seller's concurrent duty to make delivery is. In this case, the seller declines to perform so long as the buyer fails to do so. See Total Gas Marketing Ltd v Arco British Ltd [1988] 2 Lloyd's Rep 209 (HL).

${ }^{19}$ See Michael Bridge The International Sale of Goods: Law and Practice, OUP, 1999 at p 89 (para 3.29).

${ }^{20}$ See s 28 of the British SOGSA 1979 (as amended) and s 28 of the Irish SOGSA 1893 (as amended).

${ }^{21}$ Avoidance is the term that the CISG uses of what one would refer to for termination of contract in common law. The common law terminology refers to termination of contract as rescission of contract also.

${ }^{22}$ See above on the analysis on the paragraph in relation to conformity of the goods.

${ }^{23}$ As in Arcos Ltd v Ronaasen [1933] AC 470. In British Law this is subject to s 15A SOGSA 1979 (as amended), which stipulates that "where the breach is so slight that it would be unreasonable for him (the buyer) to reject the goods, then the breach is not to be treated as a breach of condition, but may be treated as a breach of condition.
} 


\section{THE DENNING LAW JOURNAL}

on fob ${ }^{24}$ and cif $^{25}$ terms require utmost strictness in their performance, this is mainly done for the pursuit of certainty. Moreover, no onerous requirement of notice is required when the contract is terminated. Thus the buyer - in the case of common law contracts of an international sale - will be entitled to terminate where the goods are shipped in time, that is outside the shipment period, as in Bowes $v$ Shand, ${ }^{26}$ where it was held that "time is of the essence". Peculiarly, what the CISG 1980 calls a fundamental breach is also found in another form in common law, on what the common lawyer would refer to it as a breach of intermediate (aka innominate) term as in Hong Kong Fir Shipping Co Ltd v Kawasaki Kisen Kaisha $L t d,{ }^{27}$ where it was said that the contract is discharged, if the other party's breach of an intermediate term deprives the innocent party of "substantially the whole benefit which it was the intention of the parties as expressed in the contract that he should obtain as the consideration for performing these undertakings." 28 Another option for a termination of contract to arise in common law is where the seller refuses to perform or is not in position to fulfil his obligations. Alternatively, one could add that a contract is simply terminated where the buyer may reject the goods. In either case the innocent party may be entitled to damages. To sum up, termination under the CISG 1980 is the case where fundamental breach arises, whilst termination of contract in common law is the case when a breach of term or intermediate term has arisen. Article 35 CISG 1980, on the other hand, does not allow the buyer to reject the goods or documents unless the breach has been fundamental, except perhaps in the case where such a buyer is entitled to anticipatory breach. In common law, however, the parties are free to withdraw unilaterally from their obligations to each other, with damages to arise in favour of the innocent party.

In relation to termination of contract, an "invention" of German inspiration is found in the CISG 1980, an invention that is not found in common law, unless of course the contracting parties expressly incorporate this in a contract under the common law; this German device is the so-called Nachfrist. Even though the CISG 1980 does not use the German term for obvious reasons, it has dramatically

\footnotetext{
${ }^{24}$ Fob is the abbreviated form of a "free on board" contract for the international sale of goods. In a contract as such it is the seller that pays the shipping costs (and usually the insurance costs) from the point of manufacture to a specified destination, at which point the buyer assumes responsibility.

25 Cif is the abbreviated form of a "cost, insurance and freight" contract for the international sale of goods. All these costs (cost, insurance, freight) are normally paid by the seller and are included in the price of the contract. In a contract as such the seller owns the goods until they are loaded on vessel. From that point of time the seller does not normally hold any further responsibility in relation to the goods.

${ }^{26}$ (1877) 2 App. Cas. 455.

${ }^{27}$ [1962] 2 Q.B. 26 at 66, per Lord Diplock L J.

${ }^{28}$ That is the innocent party.
} 
introduced the notion into its articles. ${ }^{29}$ In articles 47 (1) and 63 (1) CISG 1980 its application becomes apparent. The problem of late delivery may be successfully circumvented without the need for the whole contract to collapse as is the case in common law. Nachfrist provides some additional period for performance to the party in default, where the defaulting party has served notice of the default to the innocent party. In practical terms this means that the seller that has delayed delivery of goods or the buyer that has failed to pay the price may take advantage of some additional period that must be notified to the innocent party. The contract cannot be avoided in this case, though the innocent party is not deprived of his right to claim damages for delay in performance as Articles 47 (2) and 63 (2) CISG 1980 provide. Obviously, since time is of the essence in common law, the perception of the matter for the common lawyer is significantly different. ${ }^{30}$ It would seem that where Nachfrist is almost essential for the CISG lawyer by reason of preservation of the contractus, ${ }^{31}$ the denial of Nachfrist by the common lawyer ${ }^{32}$ is the case by reason that time is of the essence. In CISG contracts it would seem that they have to be upheld by reason of Nachfrist, whilst in common law, international contracts will only be upheld when they are respectful of the significance of the most important commodity in the international commodities markets: time.

\section{(e) Cure of contractual defects}

The fifth major incompatibility between the CISG 1980 and Anglo-Irish common law treat cure of contractual defects differently. Thus, the CISG 1980 recognises the cure of both documents and goods, whilst common law allows at most cure of documents, only where time allows. ${ }^{33}$ Under the CISG 1980 the seller may cure performance under articles 37 and 48 . What would be simply intolerable in common law, would be the fact that the seller cannot cure any defect in the goods and/or the documents after delivery has taken place, for time has to be taken to be a condition. Remarkably, under Article 48 CISG the seller may cure even after delivery has taken place. ${ }^{34}$ What is the legal result, however,

${ }^{29}$ In the English text of the Convention the term is translated as "additional period of time for performance of obligations.”

${ }^{30}$ Bowes v Shand (1877) 2 App Cas 455.

${ }^{31}$ Latin for contract or agreement.

${ }^{32}$ By "common lawyer" here British and Irish lawyers are meant. However, that is not to say that American lawyers are not common lawyers. The main difference of the latter, however, with the lawyers in the UK and Ireland is that when it comes to international trade law, the American legal system has embraced the CISG 1980, whilst the AngloIrish legal system has not.

33 Supra 30.

${ }^{34}$ That is remarkably from the British and Irish common lawyer's point of view. 


\section{THE DENNING LAW JOURNAL}

if the seller insists on repair rather than substitution of the goods? Professor Bridge suggests that under Article 46 (2) CISG 1980 the buyer can require the substitution of the goods, only in the case that the breach on the part of the seller has been fundamental. Otherwise than that, one has to construe a pro-seller stance by way of application of the good faith notion under article 7 (1) of the CISG 1980 and indeed one wonders why that should be the case from the common law point of view. It should be noted that in this latter case, if the breach is not fundamental, it is the seller who chooses either to repair faulty goods or to substitute them. ${ }^{35}$ Moreover, another complication as far as a common lawyer is concerned, is what would happen if the buyer avoids the contract by reason of fundamental breach under article 49 CISG 1980, before the seller serves a notice of attempt to cure a defect? Whilst logic would suggest that the buyer is perfectly able to do so, the CISG 1980 does not seem to follow the path of logic. Consequently, since one has to take into account that the CISG 1980 exists to uphold international contracts, a willing seller that serves notice of cure after the notice of termination on the part of the buyer may still be able to replace the goods in question and prima facie preserve the contractual arrangement. This is for two reasons: firstly the CISG must be interpreted in the light of good faith and secondly, as Honnold suggests, one has to weigh up the fundamental breach in the light of the declared or possible willingness of the seller to cure. ${ }^{36}$ At common law, apart of course from the fact that there is no such requirement of notice for an additional time fixed for the performance of obligations, there is no such onerous requirement as a notice to cure, unless the parties have agreed prior to the conclusion of their contract of sale.

\section{(f) Buyer's right to reject}

The sixth incompatibility between Anglo-Irish trade law on the one hand and the CISG 1980 on the other is the fact that a buyer in an international contract of sale under the CISG 1980 would exercise his rejection rights in a substantially different way from the common law version of international sales. Simply put the CISG 1980 does not per se recognise the "inconsistent act doctrine", since the buyer may unilaterally sell the goods in question without any negative legal consequences. The Convention, therefore, allows restitution notwithstanding resale, consumption or transformation of the goods by virtue of article 82 (2) CISG 1980, that provides for a right as such. This latter provision must be one of the most diametrically opposed provisions of the CISG 1980 towards common

\footnotetext{
${ }^{35}$ See Michael Bridge The International Sale of Goods: Law and Practice, OUP, 1999 at p 93 (para 3.34).

36 JO Honnold, Uniform Law for International Sales under the 1980 United Nations Convention, Kluwer, $2^{\text {nd }}$ Edition, 1991 at p 376.
} 


\section{THE DENNING LAW JOURNAL}

law. For instance, the English lawyer would have good grounds of principle to not even contemplate this; this because he would surmise that under s. 35 (1) (b) of the British SOGSA 1979 (as amended) and s. 35 of the Irish SOGSA 1893 (as amended) ${ }^{37}$ a buyer cannot simply reject the goods, if he has received them and thereafter "does any act in relation to them which is inconsistent with the ownership of the seller" (inconsistent act doctrine). Even more peculiarly, a buyer under article 82 (2) CISG 1980 must at least make a partial restitution of the goods, if it is impossible to make full restitution of the goods. Whereas under s. 35A of the British SOGSA 1979 (as amended) a buyer may make partial restitution only as of right. The buyer has the right to retain the remaining goods. A final difference in relation to the rejection rights is that the CISG 1980 imposes a positive obligation on the buyer under article 86 to preserve the goods in question, be it at the final expense of the seller. However, both British and Irish law by way of s.36 SOGSA 1979 (as amended) and s.36 SOGSA 1893 (as amended), clearly suggest that unless otherwise agreed, the buyer is not bound to return the goods in question to the seller. Consequently, any such buyer would have no duty to preserve the goods either, for a buyer that does not have to return goods that refused to accept them, cannot be construed as being under an obligation to preserve them.

\section{(g) Calculating damages}

The seventh great difference between the CISG 1980 and the British SOGSA 1979 (as amended) and the Irish SOGSA 1893 (as amended by SOGSASOSA 1980) the differing techniques used to quantify damages technique. For the purpose of this analysis it should suffice to say that the Anglo-Irish method of calculating damages is simpler than the action quanti minoris ${ }^{38}$ of the CISG 1980, which is a legal device of Roman law origins. By way of example, let us assume that an international contract for the sale of a cargo of maize has been concluded. The contract price for this is $£ 100,000$. By the date of delivery the goods are and s.53 (5) of the Irish SOGSA 1893 (as amended) the damages that the buyer may receive in a falling market, should be calculated as follows: nonconforming, whilst the market price of maize happens to have fallen to $£ 70,000$. In perfect condition the cargo maize would have been worth $£ 85,000$; since, however, some of the maize cargo is non-conforming the maize cargo and the

\footnotetext{
${ }^{37}$ As amended by the SOGSASOSA 1980.

${ }^{38}$ Actio quanti minoris stands for that system of calculation of damages, whereby the quantification of damages occurs by way of a reduction in price. A good analysis on this is provided by E. Bergsten and A.Miller "The Remedy of Reduction in Price” (1979) 27 American Journal of Comparative Law 255.
} 
market price thereof has fallen; its value is on delivery only £59,500. Under s. 53 (3) of the British SOGSA 1979 (as amended)

$£ 70,000-£ 59,500=£ 11,500$ (damages owed to the buyer if the sale of the contract for the international sales of goods is governed either by the laws of the UK or the Ireland).

Under article 50 CISG (action quanti minoris) the damages that the buyer may receive in a falling market, should be calculated as follows:

$£ 70,000-£ 59,500=£ 11,500$ (this amounts to $16.42 \%$ of the market price of $£ 70,000$ )

then this relevant ratio (16.42\% in our case) is applied to the initial contract price $(£ 100,000)$. $16.42 \%$ of $£ 100,000=£ 16,420$ (damages owed to the buyer if the contract for the international sales of goods is governed by the CISG 1980).

Alternatively, let us assume that the contract price is again $£ 100,000$, and that by the date of delivery the goods are again non-conforming, whilst the market price of maize happens to have increased to $£ 150,000$. In perfect condition the cargo maize would have been worth $£ 120,000$; since, however, some of the maize cargo is not conforming the maize cargo and the market price thereof has fallen, its value is only $£ 85,000$ upon delivery. Under s. 53 (3) of the British SOGSA 1979 (as amended) and s. 53 (5) of the Irish SOGSA 1893 (as amended) the damages that the buyer may receive in a falling market, should be calculated as follows:

$£ 150,000-120,000=\underline{£ 0,000}$ (damages owed to the buyer if the sale of the contract for the international sales of goods is governed either by the laws of England or the Ireland).

Under article 50 CISG (action quanti minoris) the damages that the buyer may receive in a falling market, should be calculated as follows:

$£ 150,000-£ 120,000=£ 30,000$ (this amounts to $20 \%$ of the market price of $£ 150,000$ )

then this relevant ratio ( $20 \%$ in our case) is applied to the initial contract price $(£ 100,000)$. $20 \%$ of $£ 100,000=£ 20,000$ (damages owed to the buyer if the contract for the international sales of goods is governed by the CISG 1980). 


\section{(h) Frustration}

The eighth and final difference between the CISG 1980 and common law trade rules is that they have a variant approach on frustration of the contract of sale. This time the CISG 1980 clearly departs from the Anglo-Irish law perspective rather than the American law view. ${ }^{39}$ According to Hirji Mulji $v$ Cheong Yue Steamship Co Ltd when a contract becomes frustrated common law dictates that this contract be prospectively discharged. ${ }^{40}$ Bridge suggests that this position is a rather inflexible attitude of common law, since this approach simply does not address matters such as partial or temporary frustration. ${ }^{41}$ Article 79 CISG 1980 takes a rather closer look to the American legal technique on frustration; consequently, this article broadly justifies a party's impossibility "due to an impediment beyond [this party's] control". However, this proviso neither stipulates, nor implies that the parties are discharged from their contractual obligations. In effect, if a seller cannot perform due to force majeure for instance, the buyer may well find himself paying the price of the goods that he may never have been delivered. However, that is not say that he cannot later avoid such a contract. This may be achievable through three different legal paths:

(1) either the buyer holds that the non-performance on the part of the seller is a fundamental breach as in Article 25 CISG; or

(2) he perceives the matter as one of non-performance as in article 72 CISG and the contract is repudiated; or

(3) the buyer allows the seller an extension of time to perform his duties but the seller has still not performed. In this latter case the buyer can claim restitution of money that he has already paid to the seller under article 81 (2) CISG 1980.

\section{AN INSIGNIFICANT NUMBER OF SIMILARITIES BETWEEN COMMON TRADE LAW AND THE CISG OR CONCESSIONS THAT THE CISG MAKES TO COMMON LAW SYSTEMS}

\section{(a) Specific performance}

Specific performance is recognised in the CISG 1980, though the common lawyers of the US, Canada and Australia have always felt that their fora will not

\footnotetext{
${ }^{39}$ See Michael Bridge The International Sale of Goods: Law and Practice, OUP, 1999 at p 106 (para 3.57).

${ }^{40}$ [1926] AC 497.

41 Supra at n.43.
} 
grant it as much as the Continental courts would. Farnsworth, an American academic, referred to specific performance as a remedial provision that is foreign to the common law tradition. ${ }^{42}$ Obviously, he did not mean that an American or a Canadian judge may not order the remedy of specific performance in particular, though quite rare cases, but rather he meant that the common law judges would use it less frequently than the civilian judges would. Articles 46 and 621980 expressly refer to specific performance though it is article 28 CISG 1980, which makes a significant concession to common law judges:

"If...one party is entitled to require performance of any obligation by the other party, a court is not bound to enter a judgement for specific performance..."

Therefore, it is the forum of the judgement that would most probably signify the remedy pursued, not the substantive law of the contract per se.

\section{(b) Mitigation of loss}

Another similarity between Anglo-Irish trade law and the CISG 1980 occurs in the sphere of mitigation of loss cases. By and large article 77 CISG 1980 draws a parallel line to the attitude of Anglo-Irish trade law, since under this provision the plaintiff must (after the defendant's breach of contract) take all reasonable steps to minimise losses due to this breach, in order for the plaintiff to recover damages from the defendant. In accordance with the civilian law tradition, the CISG 1980 does not pedantically stipulate the facts of the cases where mitigation of loss may occur. It merely sets out guiding principles. However, one has to take into account the diversity of legal systems that have acceded to the CISG 1980. The fora from different countries does not always present identical legal results when the mitigation of loss doctrine is applied.

\section{THE IMPACT OF THE CISG 1980: AN ANACATATAXIS RATHER THAN A TRIVIAL MATTER OF IMPLEMENTATION DUE TO THE PLETHORA OF DIFFERENCES TO BE OVERRIDDEN}

To draw an analogy, the implementation of the CISG 1980 in Anglo-Irish law would be as decisive as the full implementation of the European Convention

42 E Allan Farnsworth Discussion, in A E von Overbeck présidence, Wiener Übereinkommen von 1980, Colloquium Lausanne 19/20 November 184, (Zürich: Schulthess 1985) p 105. 
on Human Rights 1950 ("ECHR") by the UK Human Rights Act 1998. The differences between the CISG 1980 and ECHR are obvious: the former is an international instrument of law, whilst the latter is a regional instrument of law; secondly, the former will alter the way by which a national legal system (the United Kingdom and/or Ireland) will "see itself" towards other legal systems in the formation of international contracts, whilst the latter has altered the way by which the British legal system "sees itself" towards its own nationals in the pursuit of civil liberties justice. Thirdly, whilst the ECHR brought a cataclysmic change in the sphere of public law in the UK, the CISG 1980 has the potential to bring an equivalent legal anacatataxis in the sphere of British and Irish private law.

The CISG 1980 has never been welcomed in the U.K. and Ireland. Despite the fact that most of the developed world has willingly embraced the CISG 1980, including the great trading powers such as the USA, Australia, Canada, Germany, France, the Russian Federation and China, the voices for the preservation of the current status quo of trade law in the UK and Ireland well exceed those in favour of the adoption of the CISG 1980. At the preface to Benjamin's Sale of Goods, Professor Guest has made his case for the nonadoption of the CISG 1980 quite clear:

"...the Convention is not well adapted to sales on cif, fob and
other terms common in overseas sales, and its often vague or
open-textured terminology would, if it were to displace the
present relatively settled English judge-made rules governing
contracts on such terms, be a source of considerable (and
regrettable) uncertainty." 43

On the other hand, one should refer to Farnsworth, an American scholar, to understand the fears of the common lawyers, when the CISG 1980 would have to be implemented in the UK and Ireland. Farnsworth, commenting on the remedial provisions of the CISG 1980 that were in principle "foreign" to US law, once said quite colourfully:

"Fundamental breach -- OK, but strange; Nachfrist - We don't understand it, we never heard of it, but we like it; Price reduction $^{44}$-- We don't understand it, and we don't like it;

\footnotetext{
43 Benjamin's Sale of Goods, (Sweet \& Maxwell, $4^{\text {th }}$ Edition), at [ix] [Hereinafter Benjamin].

${ }^{44}$ Farnsworth refers here to what the civilian lawyers would most probably know and refer to as action quanti minoris.
} 
Specific Performance - We hope your courts ${ }^{45}$ will not resort to it as much as the may." 46

The most dismissive view on the adoption of the CISG 1980, however, has come from Professor Treitel:

“...the Convention...does not specifically deal with standard types of overseas sales (such as cif or fob contracts) while at the same time [it lays] down general rules which if applied to such contracts, would produce one of two effects. They would either produce results significantly different from those produced by the present English rules governing such sales, or (because of the lack of precision with which the Convention is drafted) cause considerable uncertainty in areas in which the present rules of English law lead to clear and easily predictable results." ${ }^{47}$

However, there have been also voices in favour of the adoption of the CISG 1980 mainly for reasons of practicability and world uniformity in the area of the international sales of goods; the leading scholars on this have been Professors Reynolds and Nicholas. Nicholas represented the UK in the drafting of the Convention. After many years, he commented that the reception by legal and commercial circles in the UK was at best mixed. ${ }^{48}$ Reynolds too has been of the opinion as one of the editors of Benjamin that the UK should adopt the CISG "as soon as possible". ${ }^{49}$

In clearly practical matters of implementation, both the UK and Ireland would not have to be concerned with whether the CISG 1980 would override the current status quo of their international trade rules. This should be the case for a good reason: under article 6 CISG 1980 the contracting parties from different states may well exclude the application of the CISG or derogate or vary its

\footnotetext{
45 That is the civilian courts when applying the CISG.

46 Supra at $n 46$.

${ }^{47}$ Benjamin at 18-004.

${ }^{48}$ Nicholas B, “The United Kingdom and the Vienna Sales Convention: Another Case of Splendid Isolation” (March 1993) Centro di Studi e ricerche di diritto comparato e straniero diretto da MJ Bonell.

49 Professor Reynolds expressed this view in "A Note of Caution" in The Frontiers of Liability, Vol 2, (P Birks ed, OUP, 1994). Reynolds signified a number of concerns about certain aspects of the Convention, however, his final point of view was that the UK should ratify the Convention.
} 
effect. $^{50}$ In effect, article 6 CISG 1980 empowers the parties to use the CISG 1980 à la carte. Even more importantly, the Convention makes allowance for considerable derogations, since for instance the contracting states may exclude considerable parts of it such as Part II (formation of an international contract of sale) or Part III (substantive rules) of the Convention as in Article 92 (1) CISG 1980.

However, if the UK and Ireland were ever to attempt to implement the "fullpackage” of the CISG 1980 then this would amount to a clear legal anacatataxis, for the international trade lawyers of these two countries would have to think of international contracts for the sale of goods in a fundamentally different way than at present, that is in CISG 1980 terms. Further, there are additional reasons for such a legal anacatataxis.

First of all, the fact that there is such reluctance to ratify the Convention should be a reason that proves the point of anacatataxis. International trade law in the UK and Ireland would never be the same. Furthermore, if the trade law of a country is divided into three: domestic trade transactions rules; domestic trade transactions vis-à-vis consumers rules and international trade transactions rules, then it would not be an exaggeration to say that good faith is now fully introduced in the Anglo-Irish legal system in trade transactions vis-à-vis consumers. Thus, even if pure common law is abortive of notions of good faith, it would seem that the reluctance of the Anglo-Irish legal system to the notion of good faith is clearly on the retreat in relation to consumer contracts post Council Directive 93/13/EEC. In connection with this and for the purposes of the CISG 1980 implementation to the international trade law branch of the Anglo-Irish legal system it would be essential that a limited notion of good faith be introduced. This, of course, would have to be the case only where a trader from the UK for instance would accept the effect of the CISG for a contract for the sale of goods with an overseas trader, e.g. one from France. Additionally, it would not be necessary for the two legal systems that would ratify the CISG 1980 to alter the domestic character of their trade laws; this would mean that it would be "business as usual" for trade transactions within the UK and Ireland. Therefore, if the traders, academics ${ }^{51}$ and judges ${ }^{52}$ from the UK and Ireland do

\footnotetext{
${ }^{50}$ Article 6 CISG 1980 stipulates as follows: "The parties may exclude the application of this Convention or, subject to article 12, derogate from or vary the effect of any of its provisions."

51 Professor Bridge in "Does Anglo-Canadian Law Need A Doctrine of Good Faith?”, Canadian Business Law Journal (1984) referred to the American legal system, which has recognised the notion of good faith to the performance and enforcement of the trade transaction as in Article 2-205 Uniform Commercial Code. Still he underlined that it would be "an abuse of the comparative method", if a principle of good faith would be introduced in the English and the Canadian legal system. Teubner too in "Legal Irritants:
} 


\section{THE DENNING LAW JOURNAL}

not want by reason of legal certainty the concept of good faith to be introduced in their domestic trade transactions within their legal systems, this should be respected. However, even this last point is arguable by operation of ss. 15A and 30 (2A) of the British SOGSA 1979 (as amended) which deal with the notion of "unreasonableness". One would be able to present this as the closest statutory approach of British trade law to a creeping form of good faith in the international trade laws of the UK. Unreasonableness could be the Trojan horse of good faith, in order for the latter to enter the international trade law branch of the British and Irish legal systems. Accordingly, article 7 (1) could be accepted by the common lawyers in Ireland and the UK. In any such case the creeping character of good faith as in the form of unreasonableness, would become a clearcut introduction of good faith, be it in the international branches of the trade laws of the UK and Ireland. This too should arguably amount to an anacatataxis.

\section{(a) Breach of term of conformity of goods}

Another point relating to the potential implementation of CISG 1980 is breach of the term of conformity of goods. Since the meaning of "particular purpose" would have to be aligned with that of the CISG 1980, then the interpretation of the common law would be confined to trade transactions either within the respective legal systems or where the parties have so agreed in international contracts. The domestic interpretation of "particular purpose" could still remain as it is in Preist $v$ Last. ${ }^{53}$ Once again the new meaning would be applied on a "voluntary" basis to international contracts, whilst the traditional interpretation of the common law would at least operate within the domestic trade transactions of the UK and the Irish legal system. ${ }^{54}$

\section{(b) Anticipatory breach}

A further reason why the CISG 1980 would result in a legal anacatataxis is that it would bring a substantially different approach on the question of anticipatory breach, which would have to be fully recognised. The partial

Good Faith in British Law", Modern Law Review (1998) has recently expressed his objections on the full introduction of good faith in British law. His conclusion has been that such an introduction would cause many problems.

${ }^{52}$ For instance, in Walform v Miles [1992] 2 AC 128 at 138 Lord Ackner has famously said that: "...the concept of a duty to carry on negotiations in good faith is inherently repugnant...[and] unworkable in practice as it is inherently inconsistent with the position of a negotiating party."

${ }^{53}$ [1903] 2 KB 148.

${ }^{54}$ That is when the parties have so intended. 


\section{THE DENNING LAW JOURNAL}

recognition of the notion in s.28 of the British SOGSA 1979 (as amended) and s.28 of the Irish SOGSA 1893 (as amended) should be extended to give full recognition to cases of anticipatory breach and in particular to such cases of anticipatory breach that are not currently recognised by the above Acts. The Anglo-Irish legislator could either choose to extend the current provisions on anticipatory breach of their sale of goods Acts or allow for a parallel system of law under a potential CISG Act that would recognise an extended version on anticipatory breach for international contracts under the CISG 1980.

\section{(c) Fundamental breach}

Moreover, an additional reason for which an anacatataxis would be a strong possibility with the implementation of the CISG 1980, would be the fact that international trade lawyers from the UK and Ireland would have to come to terms with the rather peculiar and onerous notion of "fundamental breach". Indeed, this would be one of the most difficult occurrences of alignment of any potential CISG 1980 implementation in the UK and Ireland. However, since the CISG 1980 upholds the notion of the "autonomy of the parties" the parties may well exclude its application altogether. If they include it in the contractual arrangement, then the common lawyers of the UK and the Ireland would most probably have to consult their counterparts over in the USA, for the USA is the best example of a common law system, in which the CISG 1980 has operated well. As already mentioned, "unreasonableness" is the notion that could well be the starting point not only for the partial introduction of good faith in the international trade law aspects of the common laws of the UK and Ireland but also for the comprehension of the notion of fundamental breach in the CISG 1980. This would be particularly helpful, since common lawyers would see the rationale behind the existence of this notion in the CISG 1980 and this would most importantly help their understanding on practical matters too, when they would have to comprehend and tackle cases on good faith matters in every day practice. In conjunction with fundamental breach, common lawyers in the UK and Ireland would have to come to terms with the novel legal device of Nachfrist, ${ }^{55}$ a mechanism that -if properly utilised- may give a new lease of life to the international transaction in question. In any case, it would be more than helpful for common lawyers in these countries to have a closer look at how their counterparts in other common law jurisdictions that have ratified the Convention and accepted this notion such as the USA, Canada and Australia. Additionally, it would also be advisable that the German commercial law be looked at from British and Irish business lawyers, for them to have information from the very

55 That is novel for the CISG itself but not so novel for the German trade law system, from which it derives. 
"birthplace" of the notion, since Nachfrist remains undeniably a German legal "invention".

\section{(d) Cure of defective goods and documents}

As regards cure of defective goods and documents, the CISG 1980 is clearly more "pro-contractual" than the common law rules, as this has already been suggested above. This per se should amount to an anacatataxis, if the CISG 1980 would be ever introduced in the UK and Ireland. Common law, on the other hand, remains strict to the extreme in relation to the legal results expected and in this way the contractus ${ }^{56}$ under it remains ascertained to the extreme too. Common law is, therefore, a rather more predictable legal species, when it comes to international trade law. Otherwise, than that, in the case where the CISG 1980 would be chosen to operate in a international contract, then the traders in Ireland and the UK would have to appreciate that the CISG 1980 is more lenient than the current common law rules and that it makes considerable allowances for the cure of defective goods as well as of documents. In this case an anacatataxis would be a matter of adjustment of legal mentality; that is, common lawyers would find themselves in a substantially different environment of legal technique. Further relevant sale of goods acts of both countries in question should perhaps be susceptible to slight amendments or rather to provisions that would make it clear that in case the CISG 1980 would be adopted for the conclusion of an international sale, this would allow the parties to use the full machinery of the CISG 1980 (if they so intend) and therefore be able to cure both defective goods and documents.

\section{(e) Inconsistent Act doctrine}

As regards the inconsistent act doctrine, which is explicitly recognised under s. 35 (1) (b) of the British SOGSA 1979 (as amended) and s. 35 $5^{57}$ of the Irish SOGSA 1893 (as amended), there are three possibilities on how this characteristic would have to be "watered down" for the CISG 1980 to be successfully implemented. An anacatataxis in such a case would occur either if the national legislators of the UK and Ireland would omit the above sections and thus render this doctrine obsolete or even more interestingly if they would allow these sections to continue to operate as well as recognising the mechanics of the CISG 1980 by statutory amendment on the matter or allow the preservation of the above sections but give a sufficient margin of choice to the traders to choose the mechanics of their contract by recognising their autonomy to choose the

\footnotetext{
${ }^{56}$ Supra n 35.

${ }^{57}$ As amended by the SOGSASOSA 1980.
} 


\section{THE DENNING LAW JOURNAL}

appropriate legal environment for their international contracts. In this latter case the national legislator of either country would save himself from legislating anew on his Sale of Goods Act, ${ }^{58}$ whereas it would seem that such a legislator would provide a better, less regulated environment for the traders to have the final say on the way they wish to conduct their business. This of course would be a partial revival of lex mercatoria in one sense, because it is the traders that should know trade best and it is they, who should be able freely to decide the legal tactics of conducting it.

\section{(f) Quantification of damages}

A similar pattern of law reform could be followed in relation to the quantification of damages. Again there are three paths that could be followed in relation s. 53 (3) of the British SOGSA 1979 (as amended) and s.53 (5) of the Irish SOGSA 1893; either repeal these clauses altogether, which is not suggested, however, since they have served well so far or draw a parallel provision to the existing sections or simply incorporate a freedom of choice of law clause in a potential CISG Act. The latter possibility is again seen as the least detrimental to the well-functioning of the legal system. This is so, because even though a legal anacatataxis would still be the legal result of such an Act, this would not bring disorder to the existing practices.

\section{(g) Frustration}

On the question of frustration as Professor Bridge suggests ${ }^{59}$ British law and most probably Irish law too would necessitate changes to face questions of partial or temporary frustration. This would have to be the case whether or not the CISG 1980 would be implemented. However, it would be a good starting point for the legislator to take into account the CISG 1980 solutions on this as well as the American legal techniques on the matter, from which the CISG 1980 is

\footnotetext{
${ }^{58}$ However, one would be able to speculate that the introduction of the CISG 1980 in the international subject areas of British and Irish trade laws would be introduced with a new piece of legislation in the exoteric form of the Human Rights Act 1998. This would mean that new legislation would be brought about; however, this would take a significant amount of time to be fully enforced, since for example the alignment of the whole British legislation with the European Convention on Human Rights 1950 took a period of two years until October 2, when the Human Rights Act 1998 came into force. Similarly, the partial alignment of British and Irish trade laws with the CISG would take a significant amount of time, even if the traders themselves would not be bound to choose any particular law by way of autonomy of the parties: that is CISG or non-CISG (fob, cif and their variables).

59 Supra at n 43.
} 
largely inspired. An additional point is that in any case the legislators of the UK and Ireland would have to examine carefully the application of the CISG 1980 in their "close relative" systems such as the Australian, the Canadian and the American one.

\section{CONCLUSIONS}

Firstly, the CISG 1980 remains a dynamic international trade law instrument with all its drawbacks. ${ }^{60}$ It should be able to accommodate the peculiar features of the British and the Irish legal systems and be accommodated within them. ${ }^{61}$ Secondly, these two legal systems have the potential to fully implement the CISG 1980 without significant practical difficulties as long as very careful statutory drafting in relation to the CISG 1980 is carried out. Thirdly, any such implementation would bring a major legal anacatataxis to the current status quo of the international branches of the trade laws of the UK and Ireland. Fourthly, the traders themselves would be free to choose between the application of the CISG 1980 or the "old traditional" rules of the common law of Ireland and the UK. Whether they would choose the more than a century well established precedents on fob and cif contracts or the rather more globalised and internationally accepted CISG 1980, the ultimate choice would obviously be theirs.

Whether the CISG 1980 is a lingua franca or merely an Esperanto of international trade law, this instrument of law remains the closest solution to a common set of principles for a globalised commercial law. The rather insular attitude of the United Kingdom and Ireland to the harmonization phenomenon is regrettable, whilst the anacacataxis that these systems should face in a potential case of implementation of the CISG 1980 should not be a reason that holds these systems back from ratifying the CISG 1980.

\footnotetext{
${ }^{60}$ On a balanced view in relation to the objections to the CISG one should read the article by Steyn “A Kind of Esperanto?” in P Birks (ed) The Frontiers of Liability (Oxford OUP, 1994).

${ }^{61}$ See the Law Commission's (UK) memorandum submitted to the Department of Trade and Industry on 30 October 1989.
} 